\title{
Laboratory evaluation of a novel rapid tube test system for differentiation of mastitis-causing pathogen groups
}

\author{
S. Leimbach ${ }^{1}$ and V. Krömker \\ University of Applied Sciences and Art, Faculty II, Microbiology, Heisterbergallee 10A, 30453, Hanover, Germany
}

\begin{abstract}
Because clinical mastitis, one of the most common diseases in dairy cows, is routinely treated with antimicrobial substances, it offers a high potential for future reduction of antimicrobial usage. In fact, intramammary antibiotic administration is not advisable in cases of clinical mastitis caused by coliform bacteria, yeasts, or protothecae or in cases with no detectable mastitis pathogen. To avoid unnecessary treatments with antimicrobials for the benefit of animal health and public welfare, the rapid identification of the mastitis-causing pathogens becomes necessary. Therefore, 4 different incubation time schemes for a newly developed tube test system (MastDecide, Quidee GmbH, Homberg, Germany) were analyzed in terms of sensitivity, specificity, negative and positive predictive values, and apparent and true prevalence compared with the conventional microbiological investigation results for 251 clinical mastitis milk samples from 11 dairy farms located in northern Germany. An aliquot $(100 \mu \mathrm{L})$ of a quarter foremilk sample was taken in both cases. The evaluation of the tube test result after $14 \mathrm{~h}$ of incubation at $37^{\circ} \mathrm{C}$ resulted in sensitivity values of $83.6,72.2$, and $70.7 \%$ and specificity values of $94.1,83.3$, and $90.8 \%$ for gram-positive cocci, coliform bacteria, and no growth or further pathogens, respectively. Moreover, for the present pathogen distribution, the overall tube test sensitivity was highest after $14 \mathrm{~h}$ of incubation (sensitivity $=80.9 \%$; specificity $=70.7 \%$ ). The described tube test system has the potential to provide a new option for an evidence-based mastitis therapy, with the aim of reducing the future usage of antimicrobials in dairy cows and a larger goal of decreasing antimicrobial resistance. However, a subsequent on-farm test validation should be performed before implementation in an evidencebased mastitis therapy concept can be recommended.
\end{abstract}

Received November 29, 2017.

Accepted March 7, 2018.

${ }^{1}$ Corresponding author: Stefanie.leimbach@hs-hannover.de
Key words: on-farm test, antimicrobial usage, dairy cow, treatment decision

\section{INTRODUCTION}

The development and spread of antimicrobial resistance have become a major issue for public health, threatening to cause up to 10 million human deaths annually by the year 2050 (O'Neill, 2014). Presently, about 700,000 people worldwide die of infections with multidrug-resistant bacteria every year. Intervention strategies comprise the reduction in the general usage of antimicrobials as well as the restricted use of substances with critical importance for human health (EMA, 2014). Thus, rising concerns and political pressure regarding the use of antimicrobials in veterinary medicine - especially in livestock production - increase the demand for novel tools and therapeutic concepts that can enable a prudent, optimized application of antimicrobials (Trevisi et al., 2014). In dairy production, the major proportion of antimicrobials is applied for the treatment of udder inflammation (68\%; Kuipers et al., 2016). A significant reduction of antimicrobial usage in dairy production can be achieved either directly by optimization of antimicrobial usage for clinical mastitis and dry cow treatment or indirectly by general udder health improvement (Krömker and Leimbach, 2017). The evidence-based treatment of clinical mastitis considers individual factors such as the age and lactation number of cows, mastitis history, SCC, clinical mastitis grade (IDF, 2011; GVA, 2012), and the mastitis-causing pathogen (Krömker and Leimbach, 2017).

Antimicrobial therapy can increase bacteriological cure rates above those achieved by self-healing depending on the presence of certain mastitis-causing pathogens. However, in a significant number of mastitis cases, cows do not benefit from antimicrobial treatment. In particular, earlier studies have shown that intramammary antibiotic treatment in mild to moderate clinical mastitis cases caused by gram-negative bacteria, such as Escherichia coli, does not significantly improve bacteriological cure rates (Barlow, 2011; Suojala et al., 2013; Persson et al., 2015). Furthermore, IMI caused 
by yeasts, Prototheca spp., Mycoplasma spp., or cases without bacterial growth in the conventional microbiological investigation do not justify any therapeutic antibiotic treatment (Roberson et al., 2004; Hoe and Ruegg, 2005; Lago et al., 2011a,b; Roberson, 2012). However, antimicrobial treatment of udder inflammations caused by gram-positive bacteria, especially streptococci or staphylococci, can significantly enhance bacteriological cure rates (Roberson, 2012). Thus, intramammary antibiotics can be responsibly used considering the results of a microbiological investigation (Roberson, 2003, 2012; GVA, 2012), but a cytomicrobiological laboratory investigation takes at least 48 to $72 \mathrm{~h}$, making it difficult to arrive at a timely treatment decision (Duarte et al., 2015). In fact, based on empirical results from former therapy, after this time span an antimicrobial treatment has usually at least been started if not concluded. This leaves up to $50 \%$ of the antimicrobial applications unnecessary in retrospect (Owens et al., 1997; Roberson, 2003, 2012; Neeser et al., 2006; Barlow, 2011; Lago et al., 2011a,b; Viora et al., 2014; Mansionde Vries et al., 2015). Validated rapid on-farm culture systems such as the Petrifilm system (Mansion-de Vries et al., 2014) or the Minnesota Easy Culture System (University of Minnesota Laboratory for Udder Health, St. Paul; McCarron et al., 2009; Lago et al., 2011b) are able to produce results within 24 to $48 \mathrm{~h}$, allowing earlier treatment decisions or corrections.

With the help of rapid differentiation of the pathogen group in a time span of 12 to $24 \mathrm{~h}$, a targeted treatment decision can be made without risking animal health and welfare (Guterbock et al., 1993; Neuling et al., 2011; Roberson, 2012). Intramammary antimicrobial treatment is required and recommended if the mastitiscausing pathogen is gram positive; thus, a classification of the pathogen based on the Gram staining reaction (gram-positive, gram-negative, or no growth) is sufficient and necessary for an evidence-based treatment decision (Roberson, 2012; Krömker and Leimbach, 2017). As reported by Mansion-de Vries et al. (2014, 2016), who evaluated a 24 h-Petrifilm-based treatment concept, selective intramammary antibiotic treatment of cows with gram-positive test results not only reduces antibiotic usage significantly in mastitis therapy but also does not have a negative influence on udder health. Nevertheless, further rapid test systems that can enable earlier treatment decisions while delivering easy performance, distinct result interpretation, and high consumer and handling safety need to be developed.

The objective of this study was to evaluate the performance of a novel, rapid on-farm test system (MastDecide, Quidee GmbH, Homberg, Germany) for the identification of gram-positive cocci and coliform mas- titis-causing pathogens. The described tube test system is particularly easy and safe to handle and simple to interpret. It has a shelf life of at least 6 mo if stored in a cool, dark place. The system consists of 2 test tubes containing pink test medium that can discriminate between gram-positive cocci, coliform bacteria, and no growth. A visible discoloration of the test medium after its inoculation with a $100-\mu \mathrm{L}$ sample and incubation at $37^{\circ} \mathrm{C}$ for a defined time is considered as a positive reaction. A discoloration of both test tubes indicates the growth of gram-positive cocci, a discoloration of only the first tube indicates the growth of coliform bacteria, and no change in color indicates no microbiological growth. Because some microorganisms (e.g., lactic acid bacteria, yeasts, Prototheca spp., Pseudomonas spp., Bacillus spp., Corynebacterium spp., or Trueperella pyogenes) are not able to grow in the tube system, the test will result in no growth for these microorganisms.

To evaluate the performance of the MastDecide test, the laboratory results of the new test system were compared with conventional cytomicrobiological investigation results as a reference method for 269 clinical bovine mastitis milk samples, wherein both tube tests and microbiological investigation used an inoculum of $100 \mu \mathrm{L}$. To identify the most suitable incubation time for the tube test evaluation, 4 different time periods were examined. Additionally, the resulting correct and false treatment decisions were included in the analysis.

\section{MATERIALS AND METHODS}

\section{Sample Processing}

Between April and September 2017, a total of 267 clinical mastitis samples of Holstein Friesian dairy cows from 11 farms in northern Germany, which arrived at the microbiological laboratory of the University of Applied Sciences and Arts (Hanover) for routine cytomicrobiological investigation, were included in the study. The samples with a transportation time of more than $2 \mathrm{~d}$ were excluded from the study. In case of clinical mastitis, milking personnel were instructed to collect a quarter foremilk sample according to the rules of the GVA (2009). The sampling tubes contained a boric acid-based preserving agent (Ly-20; Heeschen et al., 1969) and were stored below $8^{\circ} \mathrm{C}$ until transported to the laboratory. In the laboratory, $100 \mu \mathrm{L}$ of the wellmixed quarter foremilk sample was plated onto esculin blood agar (Oxoid, Wesel, Germany), and simultaneously $100 \mu \mathrm{L}$ was added to each of the MastDecide test tubes. After proper mixing, the test tubes and agar plates were immediately incubated at $37^{\circ} \mathrm{C}$ under aerobic conditions. 
Table 1. Classification of microbiological investigation (reference method) and estimated MastDecide (Quidee GmbH, Homberg, Germany) test results $^{1}$

\begin{tabular}{llll}
\hline Reference method & Tube 1 & Tube 2 & Result \\
\hline Gram-positive cocci & Positive & Positive & Gram-positive cocci \\
Coliform bacteria & Positive & Negative & Coliform bacteria \\
Further pathogens & Negative & Negative & No growth \\
Mixed-infection gram-positive cocci & Positive & Positive & Gram-positive cocci \\
Mixed-infection coliform bacteria & Positive & Negative & Coliform bacteria \\
Negative & Negative & Negative & No growth \\
Contaminated & Negative/positive & Negative/positive & All results possible \\
\hline
\end{tabular}

${ }^{1}$ Tube 1: positive result by discoloration due to growth of gram-positive cocci or coliform bacteria; tube 2: positive result by discoloration due to growth of gram-positive cocci.

\section{Evaluation of Rapid Test Results and Colony Growth}

The tube test results were assessed and recorded after $12,14,16,18$, and $24 \mathrm{~h}$ of incubation. A slight discoloration of the 2 test media was considered a positive result. The possible results were gram-positive cocci (positive/positive), coliform bacteria (positive/ negative), no growth (negative/negative), and invalid (negative/positive; Table 1). The person assessing the tube test results was blinded to the microbiological investigation results. The microbiological growth on esculin blood agar plates was examined and quantified parallelly after $12,18,24$, and $48 \mathrm{~h}$ of incubation by another laboratory staff member blinded to the tube test results.

\section{Microbiological Analysis}

Microbiological analysis was performed according to GVA (2009) recommendations using $100 \mu \mathrm{L}$ of wellmixed mastitis secretion. After $48 \mathrm{~h}$ of incubation at $37^{\circ} \mathrm{C}$, the number of colonies per type, colony morphologies, hemolysis patterns, and esculin hydrolysis were examined. Additionally, Gram staining performance and biochemical properties were characterized for further identification as described by Mansion-de Vries et al. (2014), and Prototheca spp. were identified microscopically.

The minimum level of $300 \mathrm{cfu} / \mathrm{mL}$ was set to claim a sample as positive for a specific pathogen; samples with less than $300 \mathrm{cfu} / \mathrm{mL}$ per colony type were categorized as negative. According to the rapid test properties, positive microbiological results were classified as gram-positive cocci (which included staphylococci, streptococci, and enterococci), coliform bacteria, or further pathogens (which included lactic acid bacteria, yeasts, Prototheca spp., Pseudomonas spp., Bacillus spp., Corynebacterium spp., or Trueperella pyogenes). Two different colony types with more than $300 \mathrm{cfu} / \mathrm{mL}$ per type were categorized as a mixed infection. Mixed infections were further divided into mixed-infection gram-positive, which contained 1 or 2 gram-positive cocci candidates, and mixed-infection coliform bacteria, which contained coliform bacteria and further pathogens but no gram-positive cocci. If more than 2 colony types with more than $300 \mathrm{cfu} / \mathrm{mL}$ per type were detected, the sample was classified as contaminated.

\section{Data Analysis}

The data were recorded in Microsoft Excel 2016 (Microsoft Corp., Redmond, WA), and the epidemiological software WinEpiscope 2.0 (http://www.winepi.net/, 10.10.2017) was used to estimate sensitivity, specificity, positive and negative predictive values, and the true and apparent prevalence with a $95 \%$ confidence interval.

To estimate the tube test accuracy, the rapid test results were compared with the microbiological investigation results with the same amount of sample (100 $\mu \mathrm{L})$ as the reference standard. The rapid test results (gram-positive cocci, coliform bacteria, no growth, and invalid) were considered false positive or false negative if the reference method did not result in confirmation (as listed in Table 1). Contaminated samples were not included in the calculations.

Overall accuracy of the results was calculated as the proportion of the sum of true positive results and true negative results divided by the total number of samples. Sensitivity, specificity, positive and negative predictive values, and the true and apparent prevalence were calculated separately for gram-positive cocci or mixed-infection gram-positive cocci, coliform bacteria or mixed-infection coliform bacteria, and no growth or further pathogens.

Additionally, the overall test characteristics were calculated for the tube test system as a whole by summing up true coliform bacteria and true gram-positive cocci results for the estimation of the sensitivity and true no growth or further pathogens results for the estimation of the specificity. Again, the rapid test results were considered false positive or false negative if the refer- 
ence method did not result in confirmation (as listed in Table 1). Contaminated samples were not included in the calculations.

Four different rapid test evaluation schemes were compared in terms of overall test accuracy, sensitivity, specificity, positive and negative predictive values, and true and apparent prevalence. The test results were evaluated after $12 \mathrm{~h}$ (scheme 1) and after $12 \mathrm{~h}$ with additional evaluation of samples showing coliform bacteria tube test results after $14 \mathrm{~h}$ (scheme 2). Furthermore, results were evaluated after $14 \mathrm{~h}$ (scheme 3 ) and $16 \mathrm{~h}$ (scheme 4) of incubation time. The possible decrease in intramammary antimicrobial doses was calculated for schemes 2 and 3 considering the therapy concept, which intends the administration of intramammary antimicrobials only in cases caused by gram-positive cocci.

\section{RESULTS}

\section{Microbiological Investigation Results}

In the conventional microbiological investigation, $28.3 \%$ of the 269 samples were classified as negative (n $=76), 31.6 \%$ were positive for gram-positive cocci $(\mathrm{n}=$ $85), 12.6 \%$ were positive for coliform bacteria $(\mathrm{n}=34)$, and $8.6 \%$ were positive for further pathogens $(n=23)$. Of the samples, $11.5 \%$ were classified as mixed-infection gram-positive cocci $(\mathrm{n}=31), 0.7 \%$ as mixed-infection coliform bacteria $(\mathrm{n}=2)$, and $6.7 \%$ as contaminated ( $\mathrm{n}$
$=18$. The detailed distribution of pathogens is listed in Table 2.

\section{Rapid Tube Test Results}

We compared the rapid tube test results of 269 quarter foremilk samples from Holstein Friesian dairy cows (across 11 farms) presenting clinical mastitis with the results of a conventional microbiological investigation of the same sample volume $(100 \mu \mathrm{L})$ to evaluate the performance and accuracy of the rapid tube test. Because we excluded contaminated quarter foremilk samples (n $=18$ ) from the test performance calculations, the rapid tube test characteristics were calculated for only 251 samples.

The grade of the overall tube test accuracy compared with the reference method varied among the 4 evaluation schemes. The results of the tube test were consistent with those of the reference method in $72.1 \%$ of the samples after $12 \mathrm{~h}$ (scheme 1), in $78.9 \%$ after $12 / 14$ $\mathrm{h}$ (scheme 2), in $76.9 \%$ after $14 \mathrm{~h}$ (scheme 3 ), and in $66.1 \%$ after $16 \mathrm{~h}$ (scheme 4 ) of incubation (Table 3). Regarding the overall test characteristics, the tube test sensitivity was highest after $14 \mathrm{~h}$ of incubation (80.9\%; Table 4).

The analysis of the test characteristics, calculated separately for gram-positive cocci or mixed-infection gram-positive cocci, coliform bacteria or mixed-infection coliform bacteria, and no growth or further pathogens

Table 2. Microbiological investigation results and the distribution of mastitis-causing pathogens in 269 clinical mastitis samples

\begin{tabular}{|c|c|c|c|c|c|}
\hline Classification & Result & $\begin{array}{c}\text { Total samples } \\
\text { (no.) }\end{array}$ & $\begin{array}{l}\text { Proportion of } \\
\text { all samples (\%) }\end{array}$ & $\begin{array}{l}\text { Total samples } \\
\text { (no.) }\end{array}$ & $\begin{array}{l}\text { Proportion of } \\
\text { all samples (\%) }\end{array}$ \\
\hline Negative & No growth & 76 & 28.3 & 76 & 28.3 \\
\hline Coliform bacteria & $\begin{array}{l}\text { Escherichia coli } \\
\text { Coliform bacteria (except Escherichia coli) }\end{array}$ & $\begin{array}{l}20 \\
14\end{array}$ & $\begin{array}{l}7.4 \\
5.2\end{array}$ & 34 & 12.6 \\
\hline Mixed infections & $\begin{array}{l}\text { Mixed infection (gram-positive cocci) } \\
\text { Mixed infection (coliform bacteria) }\end{array}$ & $\begin{array}{r}31 \\
2\end{array}$ & $\begin{array}{r}11.5 \\
0.7\end{array}$ & 33 & 12.3 \\
\hline Contaminated & Contaminated & 18 & 6.7 & 18 & 6.7 \\
\hline
\end{tabular}


Table 3. Comparison of the reference method with the MastDecide (Quidee GmbH, Homberg, Germany) test results (no. of samples) for evaluation schemes $1,2,3$, and 4

\begin{tabular}{|c|c|c|c|c|c|c|}
\hline Classification by reference & $\begin{array}{l}\text { Samples } \\
\text { (no.) }\end{array}$ & Rapid test result & \multicolumn{4}{|c|}{ Scheme $^{1}$} \\
\hline $\begin{array}{l}\text { Gram-positive cocci or mixed-infection } \\
\text { gram-positive cocci }\end{array}$ & 116 & $\begin{array}{l}\text { No growth } \\
\text { Coliform bacteria } \\
\text { Gram-positive cocci } \\
\text { Accuracy }(\%)\end{array}$ & $\begin{array}{l}24 \\
24 \\
68 \\
58.6\end{array}$ & $\begin{array}{c}24 \\
5 \\
87 \\
75.0\end{array}$ & $\begin{array}{c}9 \\
10 \\
97 \\
83.6\end{array}$ & $\begin{array}{l}7 \\
10 \\
99 \\
85.3\end{array}$ \\
\hline $\begin{array}{l}\text { Coliform bacteria or mixed-infection } \\
\text { coliform bacteria }\end{array}$ & 36 & $\begin{array}{l}\text { No growth } \\
\text { Coliform bacteria } \\
\text { Gram-positive cocci } \\
\text { Accuracy }(\%)\end{array}$ & $\begin{array}{c}10 \\
23 \\
3 \\
63.9\end{array}$ & $\begin{array}{c}10 \\
21 \\
5 \\
58.3\end{array}$ & $\begin{array}{c}5 \\
26 \\
5 \\
72.2\end{array}$ & $\begin{array}{l}4 \\
21 \\
11 \\
58.3\end{array}$ \\
\hline
\end{tabular}

${ }^{1}$ Test results were evaluated after $12 \mathrm{~h}$ (scheme 1 ) and after $12 \mathrm{~h}$ with additional evaluation of samples showing coliform bacteria tube test results after $14 \mathrm{~h}$ (scheme 2). Furthermore, results were evaluated after $14 \mathrm{~h}$ (scheme 3) and $16 \mathrm{~h}$ (scheme 4) of incubation time.

revealed that sensitivity and specificity values vary considerably (Table 5). With the elongation of incubation time, the sensitivity for gram-positive cocci or mixedinfection gram-positive cocci increases, achieving values of $58.6,75.0,83.5$, and $85.3 \%(12,12 / 14,14$, and $16 \mathrm{~h}$, respectively), whereas the specificity values decreased from $97.0 \%(12 \mathrm{~h})$ to $81.5 \%(16 \mathrm{~h})$. Contrary to this, the sensitivity for no growth or further pathogens was highest after 12 and 12/14 h (90.9\%), whereas specificity was highest after $16 \mathrm{~h}(92.8 \%)$. The sensitivity for coliform bacteria varied between $58.3 \%(12 / 14$ and 16 h) and $72.2 \%(14 \mathrm{~h})$, and specificity for coliform bacteria varied between $78.1 \%(16 \mathrm{~h})$ and $94.0 \%(12 / 14 \mathrm{~h})$.

\section{Possible Reduction in Antimicrobial Usage}

The implementation of an evidence-based therapy concept, which intends intramammary antimicrobial treatment only in clinical mastitis cases caused by grampositive cocci, theoretically enables a decrease in the intramammarily applied antimicrobial doses by $53.8 \%$ based on the results of the conventional microbiological investigation. The integration of the tube test system would have resulted in an overall reduction by $63.0 \%$ (evaluation after $12 / 14 \mathrm{~h}$ ) or $58.2 \%$ (evaluation after 14 h). The proportions of correct and false tube test-based treatment decisions are listed in Table 6 .

\section{DISCUSSION}

In the present study, we investigated the test characteristics of a newly developed rapid tube test system for on-farm differentiation of mastitis-causing pathogen groups compared with the conventional microbiological examination of the same sample volume $(100 \mu \mathrm{L})$. The newly developed tube test system is a very stable test

Table 4. MastDecide (Quidee GmbH, Homberg, Germany) overall test characteristics (\%; 95\% CI in parentheses) for evaluation schemes 1, 2, 3 , and 4 compared with the conventional microbiological investigation as the reference standard

\begin{tabular}{lcccc}
\hline & \multicolumn{4}{c}{ Scheme $^{1}$} \\
\cline { 2 - 5 } Test characteristic & 1 & 2 & 3 & 4 \\
\hline Sensitivity & $59.9(52.1-67.7)$ & $71.7(64.6-78.9)$ & $80.9(74.7-87.2)$ & $78.9(72.5-85.4)$ \\
Specificity & $90.9(85.2-96.6)$ & $90.9(85.2-96.6)$ & $70.7(61.7-79.7)$ & $46.5(36.6-56.3)$ \\
Positive predictive value & $91.0(85.4-96.6)$ & $92.4(87.6-97.2)$ & $80.9(74.7-87.2)$ & $69.4(62.5-76.2)$ \\
Negative predictive value & $59.6(51.8-67.4)$ & $67.7(59.7-75.6)$ & $70.7(61.7-79.7)$ & $59.0(48.1-69.9)$ \\
Apparent prevalence & $39.8(33.8-45.9)$ & $47.0(40.8-53.2)$ & $60.6(54.5-66.6)$ & $68.6(63.2-74.6)$ \\
True prevalence & $60.6(54.5-66.6)$ & $60.6(54.5-66.6)$ & $60.6(54.5-66.6)$ & $60.6(54.5-66.6)$ \\
\hline
\end{tabular}

${ }^{1}$ Test results were evaluated after $12 \mathrm{~h}$ (scheme 1 ) and after $12 \mathrm{~h}$ with additional evaluation of samples showing coliform bacteria tube test results after $14 \mathrm{~h}$ (scheme 2). Furthermore, results were evaluated after $14 \mathrm{~h}$ (scheme 3 ) and $16 \mathrm{~h}$ (scheme 4 ) of incubation time. 
Table 5. MastDecide (Quidee GmbH, Homberg, Germany) test characteristics (\%; 95\% CI in parentheses) calculated separately for grampositive cocci or mixed-infection gram-positive cocci, coliform bacteria or mixed infections coliform bacteria, and no growth or further pathogens for evaluation schemes $1,2,3$, and 4 compared with conventional microbiological investigation as the reference standard

\begin{tabular}{|c|c|c|c|c|}
\hline Scheme $^{1}$ & Test characteristic & $\begin{array}{l}\text { Gram-positive cocci or } \\
\text { mixed-infection gram-positive cocci }\end{array}$ & $\begin{array}{l}\text { Coliform bacteria or } \\
\text { mixed-infection coliform bacteria }\end{array}$ & $\begin{array}{l}\text { No growth or } \\
\text { further pathogens }\end{array}$ \\
\hline \multirow[t]{4}{*}{1} & Sensitivity & $58.6(49.7-67.6)$ & $63.9(48.2-79.6)$ & $90.9(85.2-96.6)$ \\
\hline & Negative predictive value & $73.2(66.7-79.7)$ & $93.4(89.9-96.9)$ & $92.9(88.5-97.4)$ \\
\hline & Apparent prevalence & $28.7(23.1-34.3)$ & $21.9(16.8-27.0)$ & $49.4(43.2-55.6)$ \\
\hline & True prevalence & $46.2(40.0-52.4)$ & $14.3(10.0-18.7)$ & $39.4(33.4-45.5)$ \\
\hline \multirow{5}{*}{2} & Specificity & $95.6(92.1-99.0)$ & $94.0(90.8-97.1)$ & $77.6(71.0-84.3)$ \\
\hline & Positive predictive value & $93.5(88.6-98.5)$ & $61.8(45.4-78.1)$ & $72.6(64.7-80.4)$ \\
\hline & Negative predictive value & $81.6(75.6-87.7)$ & $93.1(89.7-96.5)$ & $92.9(88.5-97.4)$ \\
\hline & Apparent prevalence & $37.1(31.1-43.0)$ & $13.5(9.3-17.8)$ & $49.4(43.2-55.6)$ \\
\hline & True prevalence & $46.2(40.0-52.4)$ & $14.3(10.0-18.7)$ & $39.4(33.4-45.5)$ \\
\hline 3 & Sensitivity & $83.6(76.9-90.4)$ & $72.2(57.6-86.9)$ & $70.7(61.7-79.7)$ \\
\hline \multirow[t]{6}{*}{4} & Sensitivity & $85.3(78.9-91.8)$ & $58.3(42.2-74.4)$ & $46.5(36.6-56.3)$ \\
\hline & Specificity & $81.5(74.9-88.0)$ & $78.1(72.6-83.7)$ & $92.8(88.6-96.9)$ \\
\hline & Positive predictive value & $79.8(72.8-86.9)$ & $30.9(19.9-41.9)$ & $80.7(70.5-90.0)$ \\
\hline & Negative predictive value & $86.6(80.7-92.5)$ & $91.8(87.8-95.8)$ & $72.7(66.4-79.0)$ \\
\hline & Apparent prevalence & $49.4(43.2-55.6)$ & $27.1(21.6-32.6)$ & $22.7(17.5-27.9)$ \\
\hline & True prevalence & $46.2(40.0-52.4)$ & $14.3(10.0-18.7)$ & $39.4(33.4-45.5)$ \\
\hline
\end{tabular}

${ }^{1}$ Test results were evaluated after $12 \mathrm{~h}$ (scheme 1 ) and after $12 \mathrm{~h}$ with additional evaluation of samples showing coliform bacteria tube test results after $14 \mathrm{~h}$ (scheme 2). Furthermore, results were evaluated after $14 \mathrm{~h}$ (scheme 3) and $16 \mathrm{~h}$ (scheme 4 ) of incubation time.

system, and because of its safety, ease of handling and interpretation, and reasonable shelf life, it is a suitable candidate for on-farm usage. Besides a combination of 2 Petrifilm plates (Rapid Aerobic Count and Rapid Coliform Count, 3M, Neuss, Germany) and the Minnesota Easy Culture System (University of Minnesota Laboratory for Udder Health, St. Paul), which have both been validated for on-farm use, the described tube test is one of the quickest rapid tests for diagnosis of mastitis-causing pathogen groups available at present.

With regard to the evidence-based mastitis therapy concept, the detection of gram-positive cocci for the decision of targeted antibiotic therapy represents the

Table 6. Proportions (\%) of MastDecide (Quidee GmbH, Homberg, Germany)-based correct and false antimicrobial treatment decisions calculated for 251 mastitis cases

\begin{tabular}{lcccc}
\hline Scheme $^{1}$ & $\begin{array}{c}\text { Correctly } \\
\text { applied }\end{array}$ & $\begin{array}{c}\text { Falsely } \\
\text { applied }\end{array}$ & $\begin{array}{c}\text { Correctly } \\
\text { omitted }\end{array}$ & $\begin{array}{c}\text { Falsely } \\
\text { omitted }\end{array}$ \\
\hline 2 & 34.7 & 2.4 & 51.4 & 11.6 \\
3 & 38.6 & 3.2 & 50.6 & 7.6 \\
\hline
\end{tabular}

${ }^{1}$ Test results were evaluated after $12 \mathrm{~h}$ (scheme 1) and after $12 \mathrm{~h}$ with additional evaluation of samples showing coliform bacteria tube test results after $14 \mathrm{~h}$ (scheme 2). Furthermore, results were evaluated after $14 \mathrm{~h}$ (scheme 3 ) and $16 \mathrm{~h}$ (scheme 4 ) of incubation time. main focus of the tube test system. To exclude the influence of storage and transportation to the laboratory on the results, both microbiological investigation and rapid test were performed simultaneously in the laboratory. To mimic on-farm conditions, samples were not allowed to be frozen and samples with long transportation time $(>2 \mathrm{~d})$ were excluded from the analysis to avoid artificially decreased or increased total bacterial counts. Actual on-farm tube test performance with fresh mastitis milk samples and comparatively delayed microbiological laboratory examination might have resulted in deviations in the total bacteria counts of the samples due to either long transportation time or unstable ambient temperature. Negative influence on sensitivity and specificity values might have been the consequence. Freezing of samples might have decreased the number of coliform bacteria isolations or possibly increased the isolation of Staphylococcus aureus. As freezing of samples before the tube test performance is time consuming and not intended for future usage of the test, freezing of samples was a criterion for exclusion in this study.

The allocation of sensitivity and specificity values is representative of the operation mode of the tube test, which consists of a combination of 2 indicator-based 
liquid media. Thus, a discoloration of the respective medium depends not only on the type of pathogen but also on the total bacterial count of the sample. The higher the number and the shorter the generation time of the pathogen, the faster the appearance of a color change, which explains why the sensitivity values increase with elongation of incubation time. The same mechanism explains the decrease in the sensitivity values of no growth or further pathogens samples. These samples were rarely completely free of bacterial growth, but numbers were below $300 \mathrm{cfu} / \mathrm{mL}$, resulting in a delayed color change. A shift of the threshold of 300 $\mathrm{cfu} / \mathrm{mL}$ used in the present study may therefore affect the test performance results. Application of thresholds adapted to groups such as major pathogens (100 cfu/ $\mathrm{mL})$ and minor pathogens $(200,300$, or $1,000 \mathrm{cfu} / \mathrm{mL})$ as proposed or applied by Dohoo et al. (2011), Mansion-de Vries et al. (2014), or GVA (2009), respectively, would have slightly decreased the tube test sensitivity for $S$. aureus as well as the specificity for coliform bacteria (data not shown).

Furthermore, differences in the growth patterns between the different pathogens can induce variations in the color change time. Fifteen isolates exhibited a decelerated colony growth, with no visible colonies or fewer than 50 visible colonies after $12 \mathrm{~h}$ of incubation. All of these isolates resulted in a false-negative tube test outcome. Ten out of the 18 gram-positive cocci isolates, which resulted in false-negative tube test outcome, showed such a delay in colony growth (data not shown).

Another factor influencing sensitivity is the occurrence of mixed infections. Some bacteria exhibit growth-inhibiting properties against each other, leading to false-negative results in the tube test (after $14 \mathrm{~h}$ of incubation, 8 out of 31 mixed-infection gram-positive cocci resulted in a no growth or coliform tube test result.). By excluding these mixed infections from the analysis, sensitivity values for gram-positive cocci were seen to increase slightly (data not shown). Nevertheless, the sensitivity was $83.6 \%$ for gram-positive cocci after $14 \mathrm{~h}$ of incubation, including mixed infections (n $=31$ ). Thus, the sensitivity of the tube test system for gram-positive cocci was lower compared with Petrifilm sensitivity for gram-positive pathogens (93.8, 90.0, and 85.2\%; McCarron et al., 2009; Gitau et al., 2013; and Mansion-de Vries et al., 2014, respectively) or Minnesota Easy Culture System Bi-plate (97.9 and 78\%; McCarron et al., 2009; and Lago, 2009, respectively) as reported in Lago et al. (2011a). However, the formerly described Petrifilm test system has a disadvantage in that it is not able to discriminate nonuniformly mixed growth (containing gram-positive and gram-negative pathogens) from gram-negative growth (Mansion-de Vries et al., 2014), leading to a higher number of falsely untreated gram-positive clinical mastitis cases.

Because in earlier rapid test analyses the microbiological investigation of $10 \mu \mathrm{L}$ of milk as a reference standard led to poor specificity values due to a 10-fold higher rapid test volume (Gitau et al., 2013; Mansionde Vries et al., 2014), we leveled the inoculum for the microbiological analysis to $100 \mu \mathrm{L}$ in this study. As a result, the specificity values calculated in this study were quite high and superior to the earlier reported values $(94.1 \%$ for gram-positive cocci after $14 \mathrm{~h}$ and $90.9 \%$ for the overall tube test system after $12 / 14 \mathrm{~h}$ of incubation).

The evaluation of the tube test after $12 \mathrm{~h}$ with an additional evaluation of samples showing coliform bacteria results after $14 \mathrm{~h}$ of incubation at $37^{\circ} \mathrm{C}$ (scheme 2 ) resulted in the highest overall accuracy compared with the reference method (78.9\%). However, the overall test sensitivity was higher for evaluation after $14 \mathrm{~h}$ (80.9\%) compared with scheme evaluation after 12/14 $\mathrm{h}(71.7 \%)$. Consequently, the theoretical proportion of falsely omitted antimicrobial doses is higher for evaluation after $12 / 14 \mathrm{~h}(11.6 \%)$ compared with evaluation after $14 \mathrm{~h}(7.6 \%)$. Considering the udder health and animal welfare, the terminal evaluation of the tube test should occur after $14 \mathrm{~h}$ of incubation (scheme 3), especially because the possible noteworthy reduction of antimicrobial doses diminishes only slightly from $51.4 \%$ $(12 / 14 \mathrm{~h})$ to $50.6 \%(14 \mathrm{~h})$. Gram-positive cocci tube test outcomes, which are seen much before the expiration of the incubation period, justify an immediate antimicrobial treatment of the respective udder quarter.

The tube test system was not able to identify contaminated samples. More than half $(55.6 \%)$ of the contaminated samples resulted in a gram-positive cocci, $27.8 \%$ in a coliform bacteria, and $16.7 \%$ in a no growth tube test outcome $(14 \mathrm{~h})$. As a result, under present conditions, more than half of these cows would be treated with antimicrobials, and even though it may be necessary for the remaining cows, they would not be treated. This disadvantage was also described for other rapid culture systems. Moreover, the quality of milk samples also decides the successful usage of the on-farm diagnostics that have been described. Because the tube test is unable to determine the presence of certain pathogens (i.e., further pathogens), it should be complemented by regular microbiological examinations of the herd's pathogen spectrum and the respective status of antimicrobial resistance along with close udder health monitoring (Krömker and Leimbach, 2017). Thus, one should refrain from implementing any rapid test system for therapy decision in herds that pres- 
ent Mycoplasma spp., Prototheca spp., or Trueperella pyogenes as mastitis-causing pathogens. Further investigation and on-farm test assessment are required to evaluate the actual on-farm tube test performance, the suitability as a tool for evidence-based mastitis treatment, and the possible effects on udder health and the actual reduction of antimicrobial administration.

\section{CONCLUSIONS}

The properties and characteristics of the newly developed tube test system make it a promising candidate for further on-farm usage evaluation. It is one of the quickest test systems for the differentiation of mastitiscausing pathogen groups available at present. Considering factors such as the rapid tube test accuracy, the test characteristics, and the proportion of correct and false treatment decisions, it is advisable to do the evaluation of the tube test system after $14 \mathrm{~h}$ of incubation. Thus, this study provides the basis for a resultant assessment of the actual on-farm test performance and the suitability for integration in an evidence-based mastitis therapy concept.

\section{ACKNOWLEDGMENTS}

This study was funded by the Federal Ministry of Food and Agriculture (BMEL, Bonn, Germany) based on a decision of the Parliament of the Federal Republic of Germany via the Federal Office for Agriculture and Food (BLE, Bonn, Germany) under the innovation support program. The authors declare no conflicts of interest.

\section{REFERENCES}

Barlow, J. 2011. Mastitis therapy and antimicrobial susceptibility: A multispecies review with a focus on antibiotic treatment of mastitis in dairy cattle. J. Mammary Gland Biol. Neoplasia 16:383-407. https://doi.org/10.1007/s10911-011-9235-z.

Dohoo, I., S. Andersen, R. Dingwell, K. Hand, D. Kelton, K. Leslie, Y. Schukken, and S. Godden. 2011. Diagnosing intramammary infections: Comparison of multiple versus single quarter milk samples for the identification of intramammary infections in lactating dairy cows. J. Dairy Sci. 94:5515-5522.

Duarte, C. M., P. P. Freitas, and R. Bexiga. 2015. Technological advances in bovine mastitis diagnosis. J. Vet. Diagn. Invest. 27:665672 .

EMA (European Medicines Agency). 2014. Answers to the requests for scientific advice on the impact on public health and animal health of the use of antibiotics in animals. EMA/381884/2014. European Medicines Agency, Veterinary Medicines Division/CVMP/CHMP. European Medicines Agency, London, United Kingdom.

Gitau, G. K., R. M. Bundi, J. Vanleeuwen, and C. M. Mulei. 2013. Evaluation of Petrifilms ${ }^{\mathrm{TM}}$ as a diagnostic test to detect bovine mastitis organisms in Kenya. Trop. Anim. Health Prod. 45:883886. https://doi.org/10.1007/s11250-012-0286-y.
Guterbock, W. M., A. L. Van Eenennaam, R. J. Anderson, I. A. Gardner, J. S. Cullor, and C. A. Holmberg. 1993. Efficacy of intramammary antibiotic therapy for treatment of clinical mastitis caused by environmental pathogens. J. Dairy Sci. 76:3437-3444. https:// doi.org/10.3168/jds.S0022-0302(93)77682-1.

GVA (German Veterinary Association). 2009. Leitlinien zur Entnahme von Milchproben unter antiseptischen Bedingungen und Leitlinien zur Isolierung und Identifizierung von Mastitiserregern. [Guidelines for antiseptic milk sampling and guidelines to isolate and identify mastitis pathogens.] GVA, Gießen, Germany.

GVA (German Veterinary Association). 2012. Deutsche Leitlinien Bekämpfung der Mastitis des Rindes [Guidelines for bovine mastitis control as a herd problem]. 5th ed. GVA, Gießen, Germany.

Heeschen, W., J. Reichmuth, A. Tolle, and H. Zeidler. 1969. Die Konservierung von Milchproben zur bakteriologischen, zytologischen und hemmstoffbiologischen Untersuchung. Milchwissenschaft 24:729-734.

Hoe, F. G. H., and P. L. Ruegg. 2005. Relationship between antimicrobial susceptibility of clinical mastitis pathogens and treatment outcome in cows. J. Am. Vet. Med. Assoc. 227:1461-1468. https:// doi.org/10.2460/javma.2005.227.1461.

IDF (International Dairy Federation). 2011. Suggested interpretation of mastitis terminology. Bulletin 448/2011. IDF, Brussels, Belgium.

Krömker, V., and S. Leimbach. 2017. Mastitis treatment-Reduction in antibiotic usage in dairy cows. Reprod. Domest. Anim. 52(Suppl. 3):21-29. https://doi.org/10.1111/rda.13032.

Kuipers, A., W. J. Koops, and A. Wemmenhove. 2016. Antibiotic use in dairy herds in the Netherlands from 2005 to 2012. J. Dairy Sci. 99:1632-1648. https://doi.org/10.3168/jds.2014-8428.

Lago, A. 2009. Efficacy of on-farm programs for the diagnosis and selective treatment of clinical and subclinical mastitis in dairy cattle. $\mathrm{PhD}$ Dissertation, University of Minnesota, St. Paul.

Lago, A., S. M. Godden, R. Bey, P. L. Ruegg, and K. Leslie. 2011a. The selective treatment of clinical mastitis based on on-farm culture results: I. Effects on antibiotic use, milk withholding time, and short-term clinical and bacteriological outcomes. J. Dairy Sci. 94:4441-4456.

Lago, A., S. M. Godden, R. Bey, P. L. Ruegg, and K. Leslie. 2011b. The selective treatment of clinical mastitis based on on-farm culture results: II. Effects on lactation performance, including clinical mastitis recurrence, somatic cell count, milk production, and cow survival. J. Dairy Sci. 94:4457-4467. https://doi.org/10.3168/jds .2010-4047.

Mansion-de Vries, E. M. M. Hoedemaker, and V. Krömker. 2015. Evidence-based aspects of clinical mastitis treatment. Tierarztl Prax. Ausg. G Grosstiere Nutztiere 43:287-295. https://doi.org/ 10.15653/TPG-150227.

Mansion-de Vries, E. M., N. Knorr, J.-H. Paduch, C. Zinke, M. Hoedemaker, and V. Krömker. 2014. A field study evaluation of Petrifilm ${ }^{\mathrm{TM}}$ plates as a 24 -h rapid diagnostic test for clinical mastitis on a dairy farm. Prev. Vet. Med. 113:620-624. https://doi.org/10 .1016/j.prevetmed.2013.11.019.

Mansion-de Vries, E. M., J. Lücking, N. Wente, C. Zinke, M. Hoedemaker, and V. Krömker. 2016. Comparison of an evidence-based and a conventional mastitis therapy concept with regard to cure rates and antibiotic usage. Milk Sci. Int. 69:27-32.

McCarron, J. L., G. P. Keefe, S. L. B. McKenna, I. R. Dohoo, and D. E. Poole. 2009. Laboratory evaluation of 3M Petrifilms and University of Minnesota Bi-plates as potential on-farm tests for clinical mastitis. J. Dairy Sci. 92:2297-2305. https://doi.org/10 $.3168 /$ jds.2008-1661.

Neeser, N. L., W. D. Hueston, S. M. Godden, and R. F. Bey. 2006. Evaluation of the use of an on-farm system for bacteriologic culture of milk from cows with low-grade mastitis. J. Am. Vet. Med. Assoc. 228:254-260. https://doi.org/10.2460/javma.228.2.254.

Neuling, R., J. H. Paduch, A. Bormann, C. Zinke, and V. Krömker. 2011. Evaluation of bacteriological diagnosis in secretions of clinical mastitis cases with Petrifilm ${ }^{\mathrm{TM}}$ in the veterinary practice laboratory. Tierarztl. Prax. Ausg. G Grosstiere Nutztiere 39:77-80. 
O'Neill, J. 2014. Antimicrobial Resistance: Tackling a Crisis for the Health and Wealth of Nations. Wellcome Trust, London, UK.

Owens, W. E., C. H. Ray, J. L. Watts, and R. J. Yancey. 1997. Comparison of success of antibiotic therapy during lactation and results of antimicrobial susceptibility tests for bovine mastitis. J. Dairy Sci. 80:313-317. https://doi.org/10.3168/jds.S0022-0302(97)75940 $-\mathrm{X}$.

Persson, Y., J. Katholm, H. Landin, and M. J. Mörk. 2015. Efficacy of enrofloxacin for the treatment of acute clinical mastitis caused by Escherichia coli in dairy cows. Vet. Rec. 176:673. https://doi.org/ $10.1136 / v r .102667$.

Roberson, J. R. 2003. Establishing treatment protocols for clinical mastitis. Vet. Clin. North Am. Food Anim. Pract. 19:223-234.

Roberson, J. R. 2012. Treatment of clinical mastitis. Vet. Clin. North Am. Food Anim. Pract. 28:271-288. https://doi.org/10.1016/j .cvfa.2012.03.011.
Roberson, J. R., L. D. Warnick, and G. Moore. 2004. Mild to moderate clinical mastitis: Efficacy of intramammary amoxicillin, frequent milk-out, a combined intramammary amoxicillin, and frequent milk-out treatment versus no treatment. J. Dairy Sci. 87:583-592. https://doi.org/10.3168/jds.S0022-0302(04)73200-2.

Suojala, L., L. Kaartinen, and S. Pyörälä. 2013. Treatment for bovine Escherichia coli mastitis - An evidence-based approach. J. Vet. Pharmacol. Ther. 36:521-531. https://doi.org/10.1111/jvp.12057.

Trevisi, E., A. Zecconi, S. Cogrossi, E. Razzuoli, P. Grossi, and M. Amadori. 2014. Strategies for reduced antibiotic usage in dairy cattle farms. Res. Vet. Sci. 96:229-233. https://doi.org/10.1016/j .rvsc.2014.01.001

Viora, L., E. M. Graham, D. J. Mellor, K. Reynolds, P. B. Simoes, and T. E. Geraghty. 2014. Evaluation of a culture-based pathogen identification kit for bacterial causes of bovine mastitis. Vet. Rec. 175:89. https://doi.org/10.1136/vr.102499. 